\title{
Till frågan om representation och byråkratin. Minoritetsadministratörers företrädarpraktiker i offentliga organisationer
}

\author{
Nazem Tahvilzadeh
}

SAMMANDRAG: Frågan om (o)jämlik representation och närvarons politik i politiska organisationer är central för demokratins legitimitet. Teorin om en representativ byråkrati föreslår att mångfalden i den offentliga förvaltningen tillser att olika gruppers intressen representeras i respektive organisationers beslut och verksamhet. Syftet med Nazem Tahvilzadehs artikel är att öka förståelsen för om och i så fall hur tjänstepersoner med minoritetsetnisk bakgrund i ledande befattningar företräder grupper som de identifierar sig med. Företrädarskap definieras som ett medvetet handlande att gynna en viss grupps levnadsvillkor. Det empiriska materialet består av 52 kvalitativa intervjuer i fem svenska kommuner, offentliga dokument och andra textkällor. I fokus står I2 offentliga tjänstepersoners berättelser om deras arbete och företrädarskap. Resultaten visar att företrädarskap förekommer i offentliga organisationer och att detta kan kategoriseras i sju olika praktiker inriktat gentemot enskilda individer eller gentemot policynivå. Studien aktualiserar betydelsen av representativitet i offentlig förvaltning för representativa styrelseskicks kvalitet.

NYCKELORD: etnisk mångfald; offentlig förvaltning; representation; representativ byråkrati; demokrati.

PUBLICERINGSHISTORIK: Originalpublicering.

NAZEM TAHVILZADEH är forskare i offentlig förvaltning vid Mångkulturellt centrum. E-POSTADRESS: nazem.tahvilzadeh@mkcentrum.se

FÖRSLAG PÅ KÄLLANGIVELSE:

Tahvilzadeh, Nazem (2015) "Till frågan om representation och byråkratin. Minoritetsadministratörers företrädarpraktiker i offentliga organisationer”, i Arkiv. Tidskrift för samhällsanalys, $\mathrm{nr} 4$, s. I2I-I49.

DOI: http://dx.doi.org/IO.I3068/2000-6217.4.4

(C) Nazem Tahvilzadeh/Arkiv förlag \& tidskrift 20I5 (publicerad 2 december 20I5)

Artikeln distribueras enligt en upphovsrättslicens från Creative Commons:

Erkännande-Ickekommersiell-IngaBearbetningar 3.0 Unported, som medger fri ickekommersiell användning och spridning i oförändrat skick så länge källan anges. 
Arkiv. Tidskrift för samhällsanalys är en sakkunniggranskad vetenskaplig tidskrift för samhällsvetenskap och historia. Samtliga artiklar publiceras fritt tillgängliga på:

www.tidskriftenarkiv.se

(beständig länk, DoI: http://dx.doi.org/IO.I3068/2000-62I7)

Den här artikeln finns tillgänglig i följande format:

PDF \& HTML: via beständig länk, DOI: http://dx.doi.org/IO.I3068/2000-6217.4.4 EPUB: ingår i e-boksutgåva av numret, ISBN: 978 9I 79242725

TRYCK: ingår i bokutgåva av numret, ISBN: 978 9I 79242732

Grafisk utformning och sidnumrering är identisk i pdf och tryck.

Samtliga artiklar i nr 4 (2015) nås via beständig länk, DOI: http://dx.doi.org/IO.I3068/2000-6217.4

Arkiv. Tidskrift för sambällsanalys ISSN: 2000-62I7 (för elektronisk resurs)

ISSN: 2000-6225 (för tryckta nummer)

ges ut av

Stiftelsen Arkiv för främjande och spridning av samhällsvetenskaplig och historisk forskning

genom

Arkiv förlag \& tidskrift

Box 1559

SE-22I OI Lund

BESÖк: L Gråbrödersg $3 \mathrm{c}$, ipg

TEL: O46-I3 3920

ARKIV FÖRLAG: arkiv@arkiv.nu·www.arkiv.nu

TIDSKRIFTEN ARKIV: red@tidskriftenarkiv.se · www.tidskriftenarkiv.se

ANSVARIg UTGIVARE \& CHEFREDAKTÖR: Sven Hort

ADMINistrativ RedAKTÖr: David Lindberg

RedAKtörer: Paavo Bergman, Lisa Kings, Zhanna Kravchenko 


\title{
Till frågan om representation och byråkratin. Minoritetsadministratörers företrädarpraktiker i offentliga organisationer
}

\author{
NAZEM TAHVILZADEH
}

Denna artikel handlar om representation i byråkratin. Med byråkratin avses här den offentliga förvaltningen. Jämlik representation i politiska organisationer är en central fråga för demokratins legitimitet av både symboliska och substantiella anledningar. Kvalitén i demokratiska styrelseskick beror på olika samhällsgruppers möjligheter att delta i politiskt beslutsfattande och påverka samhällets utformning. Skevheter i politiskt deltagande och hinder för individer att nå maktpositioner, på grund av deras sociala, sexuella, könsmässiga eller etniska/rasmässiga ${ }^{\mathrm{I}}$ bakgrund och tillhörighet, kan anses vara illegitima uteslutningsgrunder (Göransson $2005 \mathrm{~b}$ ). Att våra makthavare speglar samhällets mångfald är ett rättvisevärde i sig. Vi vill känna igen oss i dem som representerar demokratin och om vi inte kan identifiera oss med dem får vi intrycket att våra röster och vardagliga perspektiv och mödor inte återspeglas i maktens korridorer. Jämlik representation har ett betydelsefullt symbolvärde i det att den erkänner gruppers olika identiteter och levnadsvillkor och uttrycker en värdefull närhet mellan folket och makthavarna (Rosanvallon 20II).

Den känsla av övergivenhet som skapas bland underordnade grupper som inte känner sig representerade i maktens rum bör inte underskattas. Det bör inte heller den jämlika representationens substantiella värde. Frånvaron av personer ur arbetarklassen, kvinnor och minoriteter I. Med "ras" avses här sociala konstruktioner av skillnad och över-/underlägsenhet som kopplas till uppfattningar om individer beroende på deras utseende och hudfärg. 
har historiskt också kopplats till sämre utsikter att verka för att dessa gruppers intressen skall tillvaratas och att de ska få bättre levnadsvillkor. Representation är därför ett krav som reses av rättviserörelser som vill få till vissa politiska beslut för att förändra samhället.

Närvarons politik (Phillips 200o) är ett ständigt tema i diskussionen om demokrati och jämlikhet. Men "representation" är huvudsakligen ett begrepp som används för att beskriva relationen mellan väljare och valda och därför står oftast valda politiker i fokus. Flera partier tillämpar positiv särbehandling i olika grad för att skapa ökad jämställdhet eller mångfald på partilistorna. Politiker är också offentliga personer vars egenskaper och identiteter är föremål för större offentlig granskning och debatt än andra makthavares. Trots detta förekommer skevheter vad gäller kategorier som etnicitet/ras: minoriteter och icke-vita är illegitimt underrepresenterade (Rodrigo Blomqvist 2005; Soininen och Bäck 1999). Knappt 8 procent av svenska kommunpolitiker är "utrikes födda", att jämföra med cirka I4 procent i befolkningen som helhet (Wide 20I5, s. 32). Liknande mönster återfinns i västerländska demokratier generellt (Bird m.fl. 20Io). Medan det kan anses vara ovärdigt demokratin att politiska församlingar inte är representativa för minoritetsgrupper kan det också ses som ett konkret politiskt problem. Politikers attityder och handlingar har visat sig inte bara påverkas av partiprogram utan också av deras egna livserfarenheter och positioner i könsmässiga och etniska/rasmässiga makthierarkier (Rodrigo Blomqvist 2005; Gustafsson 2008). Närvaro förefaller därför ha betydelse för den politiska agendan och för beslut.

Närvarons politik begränsar sig dock inte till valda församlingar. Det politiska är vidare än så. De stora medierna, intresseorganisationerna, det privata näringslivets styrelser och framförallt den offentliga förvaltningens aktörer styr samhällsutvecklingen och är i vissa situationer minst lika inflytelserika som partiernas förtroendevalda. I dessa organisationer är också synliga minoritetsgrupper kraftigt underrepresenterade av illegitima skäl. Ungefär I-2 procent av exempelvis kommunala chefer eller experter har någon form av icke-västerländsk bakgrund (Karlsson och Tahvilzadeh 20IO), att jämföra med cirka IO-I5 procent i befolkningen. Uteslutningen beror inte på skillnader i faktiska kompetenser och färdigheter utan på negativ särbehandling (Göransson 2005a). Frågan om 
"mångfald" har därför politiserats allt mer i den offentliga debatten, vilket ökat relevansen för diskussionen om representation i vidare politiska fält. Att mångfalden i maktens korridorer har betydelse för respektive grupps levnadsvillkor ifrågasätts dock ofta. Varför skulle en person på basis av sin identitet eller grupptillhörighet representera och verka för någon annans intresse med liknande identitet? Identifierar sig olika minoritetsgrupper med varandra och kan personer som klättrar i samhällets statushierarkier förstå personer i sämre positioner? Kan enstaka personer egentligen påverka organisationers beslut? Är inte risken att de koopteras eller blir till alibin för maktelitens perspektiv? Få vetenskapliga undersökningar har tagit sig an frågan om hur närvarons politik påverkar politiska processer i andra domäner än politiska församlingar. Fokus i denna artikel är en central men ofta bortglömd arena för representation av minoritetsgrupper: den offentliga förvaltningen.

\section{Byråkratins makt}

Med tanke på det politiska intresset för närvarons politik finns det anledning att uppmärksamma idéer och resultat från forskning inom teorin om en representativ byråkrati (representative bureaucracy) som i huvudsak bedrivits i USA. Teorin för fram hypotesen att en offentlig förvaltning som speglar befolkningens sociala sammansättning med avseende på klass, kön, etnicitet/ras och andra relevanta sociala kategorier leder till att dessa gruppers intressen tillvaratas i förvaltningens verksamhet (jfr Wise 2003, s. 223). Bradbury och Kellough sammanfattar teorin så här:

Det antas allmänt att teorin om en representativ byråkrati säger att en mångfald inom den offentliga yrkeskåren [...] säkerställer att olika gruppers intressen representeras när policyer formuleras och implementeras (Bradbury och Kellough 2008, s. 697).

Teorin grundar sig på tre antaganden: att den offentliga förvaltningen och dess enskilda tjänstepersoner har handlingsutrymme i och inflytande över politiska processer, att deras värderingar kan kopplas till deras grupp- och identitetstillhörigheter och att dessa värderingar påverkar deras beteende i organisationen. 
Det kan vara kontroversiellt att påstå att tjänstepersoner kan påverka politiska processer utifrån sina egna värderingar, åtminstone inom ramen för en traditionell liberal förståelse av den representativa demokratin. Byråkratin är i den liberala sinnebilden av ett idealt representativt styrelseskick ett neutralt instrument i politikernas tjänst. Inom forskning om offentlig förvaltning är det allmänt vedertaget att byråkratin har en betydelsefull makt och att denna makt skapar spänningar i demokratin (Premfors 2003). Även om all offentlig makt utgår från folket förvaltas den vidare av över en miljon anställda och professionella som dagligen fattar beslut och hanterar frågor i smått och stort med ofta avgörande konsekvenser för medborgare och samhället. Hur politiska riktlinjer konkretiseras, hur lagar tolkas, hur problem identifieras, hur värden och resurser fördelas i samhället och hur det offentliga beter sig gentemot enskilda individer i den statliga maktens frontlinjer är i stor utsträckning den offentliga förvaltningens ansvar (Meier och O'Toole 2006, s. 28). Som Wamsley med flera konstaterar (1990, s. 37) kan detta ansvar användas för goda eller onda ändamål, och vilket det blir avgörs av de val som träffas av dem som styr och bemannar offentliga organisationer. Oavsett om det anses vara önskvärt eller inte har offentliga tjänstepersoner ett handlingsutrymme i utförandet av sina arbetsuppgifter. Handlingsutrymmet kan definieras som tjänstepersoners oberoende från politisk styrning, som gör att de själva kan prioritera mellan olika handlingsalternativ och fatta beslut oberoende av politikernas vilja (Denhardt och Crothers, 1998, s. 40). Detta handlingsutrymme är lika mycket ett ofrånkomligt inslag i som ett potentiellt dilemma för det demokratiska styrelseskicket.

Graden av handlingsutrymme beror på olika faktorer, inte minst vilken myndighet och vilken politisk fråga det rör sig om. I kommunpolitikens övre hierarkier, vilka är i fokus i denna artikel, är det särskilt svårt att upprätta vattentäta skott mellan "politik" och "förvaltning”. Där interagerar politiker och tjänstepersoner mer kontinuerligt och frekvent i vardagen och både svenska och internationella studier visar att ledande tjänstepersoner ofta har ett avsevärt handlingsutrymme (Mouritzen och Svara 2002; Svara 2006b; Svara 2006a; Bengtsson 20I2). I lokalpolitiken är arbetsfördelningen mellan politiker och tjänstepersoner överlappande 
och komplementär. Politiker har uppsikt över och kan blanda sig i administrationen och tjänstepersoner engageras i politikskapandet. De två parterna utövar inflytande över varandra och blir i det dagliga arbetet ömsesidigt beroende (Svara 2006b, s. I082).

Byråkratins makt skapas också genom att tjänstepersoner i regel har hög social status i samhället. Det är prestigefullt att vara ekonom, läkare, polis, planerare, generaldirektör eller kommunchef. Vi förväntar oss att dessa individer är särskilt lämpade att ta ansvar för livsviktiga frågor. Denna lämplighet ska inte bero på personliga lojaliteter, familjeband eller partibok utan enligt grundlagen ska statliga tjänster tillsättas på "sakliga grunder, såsom förtjänst och skicklighet" (Regeringsformen kap. I2, \$5, lag 20I0:I408). I saklig grund ingår dels utbildning och arbetslivserfarenheter, dels meriter. Att bedöma meriter har ett stort inslag av subjektivitet och enskilda individers värderingar och beteenden kan fà stort inflytande. Vidare kan antagandet att experter är politiskt neutrala och att "expertkunskaper" helt kan skiljas från moraliska värderingar ifrågasättas (Fischer 2009).

Detta för oss till det andra antagandet i teorin om representativ byråkrati: Påverkas de enskilda tjänstepersonernas omdöme och agerande av deras livserfarenheter kopplade till kön och social eller etnisk/rasmässig identitet och tillhörighet?

\section{Byråkratin representerar inte alla}

Framväxten av en manlig, vit och klassprivilegierad offentlig yrkeskår i moderna samhällen har varit nära förbunden med koloniala, rasistiska och sexistiska statsideologier (Ferguson 1984; Arendt 2004). Byråkratin har i marxistisk teori exempelvis bedömts vara lojala företrädare för de härskande klassernas intressen, inte minst av den anledningen att de själva tillhört och identifierat sig med dem (Albrow 1972). Byråkratins klasslojaliteter i England uppmärksammas bland annat i Donald Kingsleys Representative bureaucracy. An interpretation of the British civil service (1944), där argumentet är att arbetarklassens frånvaro från den borgerliga och aristokratiska byråkratin innebar ett stort hot mot den sociala harmonin i samhället. Att förvaltningens arbete speglades av dess anställda 
fördes också fram av amerikanska förvaltningsforskare som en utmaning för det representativa styrelseskicket (Levitan 1946). Under 1960- och I970-talet uppmärksammades frånvaron av kvinnor och etniska/rasmässiga minoriteter i den offentliga förvaltningen som ett hinder för progressiv social förändring (Kranz 1976; Krislov 1967).

Välfärdsstatens expansion och professionaliseringen av lärare, socialarbetare och andra yrkeskategorier ledde i Sverige till att personer ur arbetarklassen och i viss grad kvinnor integrerades i den offentliga förvaltningen (Norell 1989). Den ökande mångetniska/rasmässiga befolkningen är dock inte representerad i lika hög utsträckning, och studier visar att den vita svenska offentliga förvaltningen reproducerar rasifierande idéer och praktiker i relation till minoritetsgrupper. Med andra ord återskapas gruppen "invandrare" eller icke-vita som avvikande från och underlägsna en föreställd "svensk" och vit gemenskap. Dahlstedt och Hertzberg (2007) menar att idéer som utgår från en normativ vit och exkluderande "svenskhet" som privilegierad tillhörighet gör det svårare att uppnå politiska mål om invandrares deltagande i samhället. I denna logik är problemet inte politisk exkludering i sig utan att "invandraren" inte är "svensk". Andra studier har på ett liknande sätt visat hur rasifieringsprocesser präglar Försäkringskassan (Soydan 1995), Arbetsförmedlingen (Schierenbeck 2003; Hertzberg 2003) socialt arbete (Kamali 2002) och vuxenutbildning (Kalonaityte 2008). Det finns ingen lag som påbjuder systematisk bortsortering av synliga minoriteter vid rekrytering, eller andra diskriminerande praktiker i offentlig förvaltning, tvärtom är det grundlagsvidrigt. Likväl förekommer diskriminering i offentlig förvaltning, och det beror på enskilda byråkraters och organisationers handlingsutrymme.

En rad attitydundersökningar i USA visar att det finns ett samband mellan offentliga administratörers sociala grupptillhörighet och deras värderingar och politiska preferenser (Selden 1997). Kön och klassbakgrund har visat sig vara relevanta förklaringsfaktorer till gruppers intressen samt offentliga administratörers värderingar och uppfattningar om motsättningar i samhället och policypreferenser (Meier och Nigro 1976; Dolan 2000; Saidel och Loscocco 2005). Offentliga administratörer med afroamerikansk och latinamerikansk bakgrund har större benägenhet 
än andra administratörer att företräda sin respektive grupp (Bradbury och Kellough 2008; Benavides 2006; Martinez 199I; Murray m.fl. 1994). Men hur påverkar dessa attitydskillnader tjänstepersoners beteenden och organisationers processer?

En rad studier visar ett samband mellan offentliga administratörers sociala grupptillhörighet och deras beslut och verksamhetsutfall som på olika sätt gynnar respektive grupper. Till exempel har det visats att närvaron av kvinnliga och minoritetsetniska lärare och rektorer har en positiv inverkan på kvinnliga elever och elever med minoritetsbakgrund, vad gäller både studiemiljö och resultat (Meier 1984; Meier 1993; Meier och Bohte 200I; Meier och O'Toole 2006; Rocha och Hawes 2009; Keiser m.fl. 2002). Kvinnors närvaro inom poliskåren har visats ha positiva konsekvenser för åtgärder mot våld riktat mot kvinnor i hemmet (Chaney och Saltzstein 1998) och våldtäktsbrott (Meier och Nicholson-Crotty 2006). Närvaron av fler svarta anställda på organisationer som verkställer amerikanska antidiskrimineringsåtgärder har visats generera fler anmälningar av fall med afroamerikanska målsägande (Hindera 1993; Hindera och Young 1998). Andra studier finner dock inget sådant samband (Meier m.fl. 2005). Närvaron av afroamerikanska och latinamerikanska poliser har till exempel inte visats förändra tendenser till rasprofilering (Wilkins och Williams 2008). Forskning visar alltså att det finns ett samband mellan offentliga administratörers grupptillhörighet och deras värderingar och beteende, men detta samband kan inte tas för givet.

\section{Närvaro och företrädarskap}

Att mer representativa offentliga organisationer gynnar minoritetsgruppers levnadsvillkor är ett intressant samband att utforska vidare. Det finns vetenskapligt belagda samband mellan representation i organisationer och utfall som gynnar marginaliserade grupper. Vad kan detta bero på? Skapar mångfalden i organisationer normer och värderingar som förändrar arbetssätt och rutiner? Eller är det så att enskilda tjänstepersoner från marginaliserade grupper agerar på ett särskilt sätt?

Bradbury och Kellough (20II) framför att forskningen om representativ byråkrati inte tillför information om enskilda tjänstepersonernas faktiska agerande utan det antas att sambandet mellan närvaro och verk- 
samhetsbeslut beror på ett företrädarskap. Det vill säga att tjänstepersoner med minoritetsetnisk bakgrund (från och men nu kallar jag dem "minoritetsadministratörer") företräder intressen hos den grupp de identifierar sig med. I en litteraturöversikt visar Bradbury och Kellough ett samband mellan tjänstepersoners bakgrund och faktiska beteende. Inom rättsväsendet i USA agerar afroamerikanska och vita poliser och domare olika i relation till olika grupper av medborgare. Studierna visar att minoritetsadministratörer verkar för jämlika och icke-diskriminerande beslut och bemöter medborgare med minoritetsbakgrund på ett sätt som inte missgynnar dem i förhållande till majoritetsgrupper i samhället.

Några få studier försöker genom djupintervjuer och narrativa metoder återskapa hur ett eventuellt företrädarskap kan uttrycka sig. Karnig och McClain (1988) analyserar den verksamhet som sju ledande kommunala minoritetsadministratörer själva beskriver att de bedriver för att företräda minoritetsgrupper. Polischefer, vice borgmästare, stadsdirektörer och andra berättar om olika intentioner och strategier för att företräda i amerikanska storstäder. Liknande resultat visar Thurlow Brenner (2009) i en studie om kvinnliga administratörer med latinamerikansk bakgrund i amerikanska kommunförvaltningar. Hon utvecklar en empiriskt grundad rolltypologi och menar att minoritetsadministratörernas företrädarskap kommer till uttryck i olika roller. Dessa roller bestäms av individernas förhållningssätt till organisationens institutioner (strukturer och normer) och benägenhet att företräda minoritetsgrupper och kvinnor. Rolltypen "aktivister" drivs av en stark vilja att företräda minoritetsgruppens intressen och benägenhet att driva genusfrågor. De är beredda att utmana institutioner för att skapa fördelar för minoritetssamhället och kvinnor genom att skapa nya policyprogram, mobilisera resurser och säkerställa att programmen förverkligas. "Brobyggarna" skapar koalitioner och nätverk och fungerar som pragmatiska problemlösare och mellanhänder i organisationen. "Institutionalisterna" är dock inte lika benägna att företräda minoritetsgrupper (ibid., s. 844-846).

I Sverige vet vi inte särskilt mycket om varken kvinnors eller minoritetsadministratörers företrädarskap i byråkratin. Några få studier indikerar dock att företrädarskap förekommer. Bäck och Soininen (1998), som studerat den kommunala invandrarpolitiken, menar att "etniska 
tjänstemän" med utländsk bakgrund kan fungera som "mellanhänder" för invandrares intressen och krav på flerspråkig äldreomsorg och hemspråksundervisning i olika kommuner (ibid., s. 158). Rodrigo Blomqvist (2005, s. 209), som egentligen sökte efter politikers företrädarskap för invandrargrupper, fann att tjänstepersoner med finsk bakgrund hemspråkslärare, psykologer och ledande administratörer - agerat som "resurspersoner" för finska föreningars krav på finskspråkig grundutbildning. Hon pekar på att förutsättningen för att den finskspråkiga skolfrågan skulle föras upp på dagordningen och nå framgång $\mathrm{i}$ beslutsprocessen var att gruppen hade "representanter" i kommunförvaltningen. Kamali (2002), som studerat socialarbetare med utländsk bakgrund, menar dock att klienter med minoritetsbakgrund upplever att minoritetsadministratörer är hårdare i sina bedömningar och beslut än svenskfödda.

Forskningsresultat pekar alltså åt olika håll. Syftet med denna artikel är att öka förståelsen för om och i så fall hur minoritetsadministratörer i ledande befattningar företräder grupper som de identifierar sig med.

En närmare definition av det belastade begreppet "representation" behövs för en vidare tillämpning. Jag tar vara på Hendersons (I978) begrepp "advocacy" (försvarande, befrämjande eller kamp för något) och översätter det till "företrädarskap". Henderson skiljer mellan de symboliska aspekterna av afroamerikanska administratörers egenskaper och hur de faktiskt talar och handlar för att främja en grupps intressen. Det senare definieras som en tjänstepersons handlingar i strävan att vara lyhörd för en särskild grupps uttalade policypreferenser. Att endast definiera företrädarskap i relation till uttalade intressen kan dock osynliggöra handlingar som utgår från administratörernas egna uppfattningar om "gruppens bästa", som ingen grupp själv har artikulerat. Jag definierar därför företrädarskap som offentliga tjänstepersoners intention och medvetna handlande utifrån sin identitet och grupptillhörighet med avsikt att förbättra en viss grupps levnadsvillkor. Att agera som företrädare kan enligt denna definition innebära att verka för uttalade intressen, men också att sätta upp och uppnå mål i enlighet med sina egna uppfattningar och analyser (Thompson 1976). 


\section{Metod}

Jag har genomfört en explorativ, intensivt strukturerad och jämförande fallstudie (Danermark m.fl. 2002). Det centrala empiriska materialet består av tolv minoritetsadministratörers arbete och uppfattningar. Urvalet av dessa individer styrdes av kriterierna synlig minoritetsbakgrund, ursprung i icke-västerländska länder direkt eller genom föräldrar, så hög position som möjligt i den kommunala hierarkin, samt jämn könsfördelning. Utgångspunkten för urvalet var en bredare kartläggning av en första urvalsgrupp: efter ovanstående principer kartlade jag minoritetsadministratörer i 50 större svenska kommuner genom att söka efter icke-västerländska namn på hemsidor och i personalkataloger eller få information av receptionister eller liknande.

Tio av de tolv intervjuade arbetade eller hade arbetat med mångfaldsoch integrationsverksamhet. Det har stor inverkan på deras berättelser. Endast en av de intervjuade är högste kommunchef, kvinnor är i minoritet och ingen av de intervjuade har afrikansk bakgrund eller identitet.

Utöver minoritetsadministratörerna har jag intervjuat 25 andra respondenter: politiker, administratörer och föreningsrepresentanter. Sammanlagt genomförde jag 52 intervjuer i fem kommuner mellan 2006 och 20II.

Minoritetsadministratörernas egna berättelser om huruvida och hur de företräder minoritetsgrupper har varit den huvudsakliga informationskällan. Dessa berättelser har vägts mot andra respondenters perspektiv samt uppgifter i offentliga dokument och medier som sätter in berättelserna i ett sammanhang. Tillsammans ger källorna en bild av hur företrädarskapet formas utan att jag behöver observera det direkt eller på förhand ställa upp kategorier för vad det kan innebära. Bilden är inte fullständig men visar viktiga aspekter av det som studien avsett att fånga.

Analysen av företrädarpraktiker utgår från ett semistrukturerat samtal som börjar med att respondenterna berättar om sina yrkesroller och sin relation till den egna etniska identiteten och sedan ombeds att ta ställning till huruvida de vill företräda minoritetsgrupper och i så fall hur de försöker göra det, med konkreta exempel. Det vore önskvärt att återge de känslor, tolkningar och berättelser som minoritetsadministratörerna 
delat med sig av eftersom de levandegör de företrädarpraktiker som presenteras nedan, men det ryms inte inom ramen för denna artikel (men jfr Tahvilzadeh 20II, kap. 5-IO).

En betydelsefull kuliss för minoritetsadministratörernas berättelser är att Sverige under perioden präglats av invandring och flyktingar från bland annat Östeuropa, Mellanöstern och Afrikas horn. Traditionella arbetarkommuner med en stor andel hyresrätter blir mottagare för majoriteten av de nyanlända. I dessa kommuner är politiseringen kraftigare än i andra kommuner och frågor om mottagandets administration, avsaknad av sysselsättning, social oro i stadsdelar där nyanlända koncentreras och andra spänningar mellan minoritets- och majoritetssamhället blir centrala i politiken. Mitt urval präglas av denna typ av kommuner och kommuner där frågan om det mångetniska är mindre politiserad.

\section{Företrädarpraktiker i offentlig förvaltning}

Studien visar att företrädarskap förekommer men att det är beroende av en rad villkor. För det första är det inget som alla minoritetsadministratörer vill eller kan ägna sig åt i sin yrkesroll. Vissa upplever att det aldrig varit aktuellt, medan andra upplever att det har varit aktuellt i avgränsade skeden i karriären (för en analys av de faktorer som formar intentionen och förutsättningar att företräda, se Tahvilzadeh 20II, s. 223-244). Nedan analyserar jag berättelser om företrädarskap som finns i materialet. Det har inte rått någon brist på material att analysera men det går inte att uttala sig om hur vanligt företrädarskap är i offentlig förvaltning utifrån denna studie - det vi kan konstatera är att det förekommer sju typer av företrädarpraktiker. Med praktiker avses mönster av handlingar med vilka minoritetsadministratörer försöker att forma organisationen och omvärlden efter sina egna intressen och projekt enligt följande process (Archer 2003, s. I32):

$$
\text { INTRESSEN } \rightarrow \text { PROJEKT } \rightarrow \text { PRAKTIKER }
$$

En praktik blir till när minoritetsadministratörer omsätter visioner och strategier i sina projekt till handlingar, och den behöver inte vara framgångsrik för att definieras som företrädarskap. Det är också viktigt att 
påpeka att de intressen som minoritetsadministratörer uttrycker som grund för sitt företrädarskap utgår från visioner om ett mångetniskt jämlikt samhälle med lika rättigheter och möjligheter för alla och fritt från de problem som minoritetsgrupper upplevs ha: arbetslöshet, maktlöshet och social och ekonomisk marginalisering med mera. Visionerna kan också innefatta att skapa ett samhälle utan rasism, diskriminering och förtryck mot kvinnor. Det finns olika strategier för att förverkliga visionerna, och de är i sin tur knutna till de praktiker som minoritetsadministratörerna utövar. Självklart gör olika minoritetsadministratörer olika analyser av vad som ligger i minoritetsgruppers intressen och hur dessa intressen bäst tillgodoses.

Vi kan översiktligt identifiera tre typer av projekt. Den första typen betonar mångkulturella strategier som innebär att specifika minoritetsgruppers identiteter bevaras och utvecklas. Det kan handla om att etablera trossamfund, institutioner och aktiviteter med syftet att bevara och utveckla gruppens identitet, trosuppfattning och etniska och kulturella särart i relation till andra etniska grupper. Det finns också projekt som relaterar till situationen i hemlandet. Minoritetsadministratörer som driver dessa projekt kan som privatpersoner vara engagerade i lokala eller nationella föreningar för den specifika gruppen och se självorganiseringen som en viktig del i gruppens välbefinnande.

Den andra typen av projekt formuleras mer övergripande och utgår från ledord som upplevs vara relevanta för alla minoritetsgrupper eller till och med alla medborgare: "rättvisa", "jämlikhet", "jämställdhet", "mångfald" eller "integration". Strategierna i dessa projekt är generella rättvisestrategier och inriktar sig på att förändra majoritetssamhällets strukturer genom att till exempel bekämpa arbetslöshet, öka gruppens deltagande och inflytande i politiken eller bekämpa diskriminering och rasism.

Den tredje typen av projekt utgår från strategier på individnivå och fokus ligger på att minoriteter ska anpassa sig till det nya samhället. Dessa assimilerande strategier inriktar sig på att förändra beteendet hos minoritetsgrupper i syfte att stärka deras position i det svenska samhället, till exempel genom att betona behovet av insatser för att öka minoritetsgrup- 
pers kunskaper i svenska språket och kulturen samt höja deras utbildningsnivå och stärka deras konkurrenskraft på arbetsmarknaden.

Minoritetsadministratörernas projekt för mångetnisk jämlikhet präglas alltså av olika visioner och projekt. Det är ingen överraskning att olika minoritetsgrupper har olika idéer om det ideala samhället och hur det bör uppnås. Olika intressen och projekt kan dock samsas om samma företrädarpraktiker. De sju olika företrädarpraktikerna som presenteras nedan tar sin utgångspunkt i ett flertal olika sakfrågor: föreningsverksamhet, brottsförebyggande och socialt arbete, stadsutveckling, tillväxt, arbetsmarknadsfrågor, personalpolitik, integration, mångfaldspolitik och flyktingpolitik med mera. Praktikerna är företrädarskap eftersom minoritetsadministratörens intention är att förbättra minoritetsgruppens villkor i samhället. Olika minoritetsadministratörer kan ägna sig åt en eller flera av de olika företrädarpraktikerna.

Företrädarpraktikerna kan gälla ärenden som berör enskilda individer eller föreningar eller frågor på en högre principiell nivå. De senare praktikerna har syftet att åstadkomma principiella förhållningssätt, program och aktiviteter för hela eller delar av organisationens verksamhet. Det kan handla om program som riktar sig till minoritetsgrupper eller om generella frågor, till exempel riktlinjer för stöd till invandrarföreningar eller insatser för att öka medvetenheten om mångfald och integration i den egna organisationen.

Företrädarpraktikerna kan utövas på interna eller externa forum. Interna forum är kommunorganisationens ärendehantering och policyprocesser. Externa forum inkluderar privata, regionala, statliga och internationella organisationer, medier och det övriga samhället där administratörerna deltar i sina yrkesroller.

De sju företrädarpraktikerna sorteras i figuren här ovan utifrån dessa två dimensioner. Utefter in riktning (enskilda ärenden eller övergripande policy) och forum (internt i kommunorganisationen eller externt i andra forum) kan företrädarpraktikerna delas upp i fyra kategorier, som tydliggör deras variation och fördjupar förståelsen för hur administrativt handlingsutrymme kan användas för att företräda minoritetsgrupper. 


\section{Företrädarpraktikernas dimensioner}

\begin{tabular}{|c|c|c|}
\hline & & TNING \\
\hline & Enskilda ärenden & Övergripande policy \\
\hline 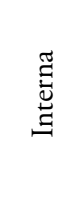 & $\begin{array}{l}\text { Vägledning } \\
\text { Förespråkande }\end{array}$ & $\begin{array}{c}\text { Policyskapande (problemformulering, } \\
\text { utformning av policydokument och } \\
\text { policypraxis) } \\
\text { Policyförverkligande } \\
\text { Predikande }\end{array}$ \\
\hline 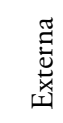 & $\begin{array}{l}\text { Vägledning } \\
\text { Förespråkande }\end{array}$ & $\begin{array}{c}\text { Koalitionsbyggande } \\
\text { Mobilisering } \\
\text { Predikande }\end{array}$ \\
\hline
\end{tabular}

\section{Vägledning}

Vägledande företrädarpraktiker innebär att minoritetsadministratören i enskilda ärenden tillhandahåller information och råd som kan ge enskilda individer eller grupper större insyn i offentliga organisationers myndighetsutövning och fördelning av resurser. Minoritetsadministratörerna är erfarna spelare i de offentliga institutionella miljöerna. Vid sidan om kunskaper om relevanta lagar och regler samt formella och informella procedurer har de också en förmåga att finna lämpliga vägar fram när dörrar förefaller vara stängda för andra. Enskilda individer kan uppsöka minoritetsadministratören för råd och stöd i frågor om myndighetsvärldens regler, rutiner, instanser och beslutsprocesser inom den kommunala verksamheten. Det kan handla om introduktionsprogram, försörjningsstöd, föreningsbidrag, skol- eller omsorgsfrågor eller ärenden som berör andra myndigheter som Migrationsverket, Försäkringskassan, Arbetsförmedlingen, Polisen med mera. Ledande administratörer har generellt inte denna funktion som formell arbetsuppgift, men enskilda individer med minoritetsetnisk bakgrund kan på eget initiativ kontakta, 
eller av kommunens reception hänvisas vidare till, minoritetsadministratören. Den som söker vägledning kan vara en obekant person eller en anhörig, släkting, vän, bekant eller granne. Det kan vara någon som söker arbete och saknar information om hur offentliga rutiner är utformade och hur beslut fattas i vissa frågor. Det kan också vara någon som har utsatts för diskriminering och vill ha upprättelse eller en föreningsrepresentant som vill ha information om föreningsbidrag, hur stadgar ska formuleras eller hur lokaler kan hyras för evenemang eller för moskéeller kyrkoförsamlingen.

\section{Förespråkande}

Minoritetsadministratörerna kan engagera sig i enskilda ärenden genom att förespråka ett visst beslut eller utfall. Förespråkande kan ses som ett mer omfattande åtagande än vägledning eftersom minoritetsadministratören anstränger sig för att få till stånd ett önskvärt resultat och beslutsutfall i frågan.

Förespråkandet kan gälla enskilda individer. Till exempel kan minoritetsadministratören påverka ett avslagsbeslut angående försörjningsstöd genom att medla, förtydliga och nyansera sökandens situation i dialog med handläggaren; förespråka eller direkt anställa individer med minoritetsetnisk bakgrund i rekryteringsprocesser; formulera överklaganden i ärenden eller förhandla med berörda handläggare på den egna myndigheten men också på andra myndigheter för att uppnå önskat resultat; nominera individer till utmärkelser för engagemang i till exempel integrationsfrågor; och hjälpa individer som upplevt diskriminering att få upprättelse.

Förespråkandet kan också gälla grupper av individer. Till exempel kan minoritetsadministratören förespråka att resurser - pengar, lokaler och andra stärkande insatser - kommer enskilda föreningar till del; agera som språkrör för intressen som föreningar manifesterar (en fotbollsförening som behöver medel för en arena, en muslimsk förening som vill bygga en moské, en kulturförening som vill utöka sina aktiviteter); gästa föreningar som föreläsare eller talare eller stå som kontaktperson i relation till kommunen i syfte att ge föreningens aktiviteter medvind och uppmärksamhet; och hjälpa icke-organiserade grupper av individer som upplevs ha 
behov av stöd eller uppmärksamhet genom att till exempel skapa en samlingsplats för arbetslösa äldre män eller inrätta befattningar på en grundskola som ska förbättra relationen mellan föräldrar och lärare.

\section{Policyskapande}

Policyskapande företrädarpraktiker inriktar sig på övergripande perspektiv, rutiner och handlingsinriktningar i organisationen och har potential att påverka den framtida verksamheten. Genom policyskapandet engagerar sig minoritetsadministratörer för att utforma den lokala politiken på ett sätt som gynnar minoritetsgruppers levnadsvillkor. Kommunala chefer och experter har i den empiriska undersökningen visat sig vara involverade i kommunens övergripande policyprocesser och i ledningsarbetet. Ledande administratörer ges möjlighet att kontinuerligt delta i arbetet med att forma kommunens politik i små och stora frågor: Hur ska organisationen se på mångfald och integration? Hur ska den tillämpa statliga politiska program? Hur ska staden utvecklas, demokratin fördjupas, segregationen brytas, stadsdelar utvecklas, arbetslösheten motverkas? Kommunala ledande administratörer ansvarar inte bara för att leda organisationen och styra personal, även om en stor del av deras handlingsutrymme skapas av att de kontrollerar organisationens resurser. Kommunens ledande politiker är också beroende av administratörerna för att, som Mouritzen och Svara (2002) beskriver, skapa nya politiska förhållningssätt och insatser för att möta behov i ett föränderligt samhälle. Ledande kommunala minoritetsadministratörer deltar på så sätt $\mathrm{i}$ att formulera idéer och visioner, initiera nya projekt, mobilisera resurser och säkerställa att de används effektivt i olika frågor. När de agerar rådgivare till politiska och administrativa ledare skapas ett ömsesidigt beroendeförhållande mellan politik och förvaltning. Minoritetsadministratörerna kan använda detta handlingsutrymme till att skapa policy med syftet att förbättra minoritetsgruppers levnadsvillkor. Denna praktik kan delas in i tre delar: problemformulering, utformning av policydokument och utformning av policypraxis.

PROBlemformulering. Hur de frågor och problem som den kommunala organisationen har att arbeta med ramas in formar de världsbilder som organisationens aktörer förväntas agera utifrån. Problemformule- 
ring består huvudsakligen i tolkande och kunskapsproducerande arbetsuppgifter där policyskaparens världsbild och värderingar kommer till uttryck: Vad är problemet som behöver lösas? Minoritetsadministratörer kan ha framträdande roller i problemformuleringen i samband med skapande av policy. Målet är att synliggöra hur samhället upplevs och ser ut ur minoritetsgruppers perspektiv.

Minoritetsadministratörer kan göra anspråk på att deras erfarenheter som minoriteter är relevanta för policyarbetet. Som flyktingar, invandrare, deltagare i introduktionsprogram och andra utbildningar för invandrare, arbetssökande, boende i minoritetstäta stadsdelar, diskriminerade och rasifierade med anledning av sin etnicitet/ras vill de förändra samhällets maktordning och invandrares sociala position. Minoritetsadministratörerna kan också göra anspråk på att ha stor kännedom om minoritetsgruppers levnadsförhållanden. Livs- och arbetserfarenheter och förenings- eller partiengagemang ger dem tillgång till kontaktytor med och informationskällor om minoritetsgrupper. Dessa erfarenheter kan de återge för att påverka hur problem formuleras i syfte att bättre spegla behov och perspektiv. Erfarenheterna kan de ha fått när de har arbetat i stadsdelar med en stor koncentration av minoritetsgrupper, men släkt, vänner och bekanta kan också bidra.

Dessa verklighetsbilder kanaliseras in i policyskapande processer på olika sätt. De förmedlas genom exempelvis utredningar, rapporter och pm i beredningen av beslut för att påverka beslutsfattarna i diskussioner på formella och informella möten. Vad händer på arbetsmarknaden? Vilka nedskärningar påverkar dessa stadsdelar? Vad orsakar brottslighet förutsatt att etnisk bakgrund inte är en förklaring i sig? Är kulturell mångfald negativt för ett samhälle? Vad betyder tillväxt? Vad händer i moskén? Vilka intressen har den albanska föreningen? Omvärlden tolkas på ett sätt som förväntas leda till åtgärder som är gynnsamma för minoritetsgruppers levnadsförhållanden.

UTFORMNING AV POLICYDOKUMENT. Ett sätt att forma övergripande processer är att formulera policydokument som tydliggör önskvärda förhållningssätt och handlingsplaner. På så sätt kan minoritetsadministratörer företräda politiska åtgärder som uppfattas gynna minori- 
tetsgrupper. Dessa dokument är lång- och kortsiktiga handlings- och verksamhetsplaner, budgetar eller program. Exempel på policyplaner är integrationspolitiska program, mångfaldsplaner, strategidokument för stadsutveckling, personalpolitiska program och övergripande mål- och styrningsdokument för kommunpolitiken. Policydokumenten kan innehålla en ideologisk aspekt i det att kommunens åsikter om och visioner för det mångetniska samhället konkretiseras.

Företrädarskapet kommer till uttryck i att minoritetsadministratörerna får till stånd visioner om mångetnisk jämlikhet, motstånd mot rasism och ökad välfärd och delaktighet i samhället för minoritetsgrupper. När de utformar policydokument försöker minoritetsadministratörerna specificera konkreta, effektiva och realistiska åtgärder för att förbättra minoritetsgruppers levnadsförhållanden, till exempel genom att driva frågan om mångfald i personalpolitiken eller påverka budgetdokument för att få in skrivelser som ålägger organisationen att arbeta med mångfaldspolitiken.

UTFORMNING AV POLICYPRAXIs. Minoritetsadministratörerna kan också skapa policy genom att tolka befintliga policydokument och utforma en policypraxis. Denna praxis utgår från tolkningar av visioner för integration, mångfald eller stadsutveckling som formulerats på statlig eller kommunal nivå. Praxisen fyller visionerna med konkreta mål och arbetsuppgifter som formas i det dagliga arbetet. Praxisen kan följa den anda som formuleras i övergripande styrdokument men omtolkas i linje med minoritetsadministratörens projekt. De kommunala organisationernas verksamheter styrs av en rad olika nationella och lokala politiska handlingsprogram. Dessa kan stå i konflikt med varandra eller konkurrera om politikers och administratörers uppmärksamhet vilket skapar situationer där enskilda administratörers överväganden och tolkningar kan få avgörande betydelse för det som görs i praktiken. Hur bör organisationen arbeta för att motverka rasism, skapa mångfald, förbättra folkhälsan, bryta segregation, förebygga brottslighet, mobilisera de boende i en stadsdel och skapa delaktighet i praktiken? Minoritetsadministratörerna kan prioritera egna strategier i arbetet med mångfalds-, integrations- eller stadsutvecklingspolitiken. De kan också tolka andra centrala 
utvecklingsdokument, så som kommunala utvecklingsdokument eller budgetplaner, för att uppnå ett mångetniskt jämlikt samhälle.

\section{Policyforverkligande}

De mål som ställs upp i ett policydokument eller av en policypraxis behöver inte per automatik förverkligas i organisationens processer. Detta blir särskilt påtagligt när målen berör hela organisationens värderingar och sätt att arbeta. Policyförverkligande företrädarpraktiker handlar om att säkerställa att mål som har till syfte att gynna minoritetsgruppers levnadsvillkor förverkligas. Minoritetsadministratörer kan också drivas av viljan att förverkliga policy i organisationens arbete. Policyskapande och policyförverkligande kan ses som överlappande. Måste inte en policy prägla kommunens verksamhet för att få kallas en policy? Utgångspunkten här är att policyskapande är intimt förknippat med men ändå skilt från policyskapande. De kan ses som olika steg i den politiska processen. Att kommunerna har skriftliga handlingsplaner, politiska program och styrdokument om att verka för mångetnisk jämlikhet och alla medborgares välfärd är ingen garant för att det förverkligas. Ledande minoritetsadministratörer kan alltså försöka förverkliga policyn i verksamheten. Detta innebär att i ledningsgruppers och politiska nämnders arbete bevaka en särskild fråga och försäkra att den genomsyrar andra administratörers och politikers beslutsfattande och agerande. Minoritetsadministratören blir en form av kontrollant för olika delar av verksamheten, till exempel genom att se till att integrations- och mångfaldsperspektivet genomsyrar organisationens verksamhet och beslutsfattande. Ett annat sätt att verka som kontrollant är att handfast engagera sig i verksamhetsstyrning genom att förverkliga policy på egen hand. Det kan handla om att ta på sig ansvaret för att förverkliga en policy i en specifik situation, till exempel om det uppstår social oro i en stadsdel. Policyförverkligande företrädarpraktiker innebär också att upprätta en administrativ infrastruktur och styrmodell som på olika sätt stärker policyns möjligheter att förverkligas i organisationen. Det mobiliserar resurser för att möjliggöra fler aktörers insatser i arbetet med särskilda mål, till exempel icke-diskriminerande rekryteringsprocesser eller motverkandet av boendesegregation $i$ en stad. Man kan mobilisera resurser genom att påverka budget- och 
verksamhetsplaner i organisationen eller genom att formulera projektansökningar till olika internationella, nationella, regionala eller kommunala projektutlysningar. Dessa resurser kan stärka implementeringen av policy och förverkliga de visioner som minoritetsadministratörer har.

\section{Predikande}

Predikande företrädarpraktiker har syftet att deklarera ståndpunkter, inspirera, öka medvetenhet, mobilisera viljekraft och påverka andra aktörer genom att förmedla idéer, kunskap, argument och moraliska perspektiv för att uppnå ett visst policyresultat. Kommunikation och deliberation är nödvändiga arbetsinstrument i offentlig förvaltning. Policyskapande och policyförverkligande föregås av analys, tankeverksamhet och dialoger med andra. Förr eller senare måste dock kunskaper, perspektiv och bilder av omvärlden spridas i organisationen och samhället. Även om prat är centralt för administrativa processer finns det aktiviteter som uteslutande inriktar sig på att sprida idéer, perspektiv och argument för att övertyga och övertala andra aktörer, till exempel organiserade föreläsningar, inlägg i debatter, e-post, publicerade skrifter, intervjuer med medier, seminarier och tal. Genom predikandet sprids perspektiv och åsikter med strävan att gynna minoritetsgruppers situation i samhället, till exempel genom att påverka dominerande perspektiv på och ideologier om det mångetniska och minoritetsgrupper i organisationen eller samhället. Predikandet kan ta mångfalden, invandrarna och flyktingarna i försvar och framställa dem som resurser för samhället eller sprida positiva bilder av uppmärksammade stadsdelar genom att till exempel uttala sig gillande om ett bostadsområdes mångetniska sammansättning. Minoritetsadministratörers motstånd mot rasism kommer inte sällan till uttryck i predikande.

Minoritetsadministratörerna kan ha i uppdrag att utbilda personalen i mångfalds- och integrationsfrågor eller att genom särskilda tidningar och andra publikationer sprida perspektiv på och kunskap om det mångetniska. Minoritetsadministratörer bjuds in som talare vid offentliga möten, seminarier och konferenser och ombeds att ge sin syn på olika ämnen. Predikandet kan också komma till uttryck i informella sammanhang där minoritetsadministratörerna söker påverka, förändra eller göra motstånd mot ett sätt att tänka på, prata om eller förstå ett problem som 
rör det mångetniska i organisationen. Genom "fikarumsaktivism" agerar minoritetsadministratörer för att försvara invandrare mot rasistiska åsikter.

Predikandet riktas inte bara till den kommunala organisationen utan även till andra aktörer i samhället: näringslivet, det civila samhället, medier och andra offentliga organisationer. På olika sätt och i olika sammanhang ges minoritetsadministratörerna möjlighet att förmedla sina perspektiv på frågor som rör det mångetniska. Målet med predikan kan vara att påverka den lokala opinionen eller en annan organisations verksamhet. Detta kan ske på olika tillställningar och möten, exempelvis konferenser, högtidsceremonier och offentliga debatter. En annan arena för predikandet är de lokala medierna. Särskilt tydligt är det i samband med rapportering eller berättelser om händelser i oroliga bostadsområdena med hög andel invandrare.

Predikandet kan också vara ett sätt för minoritetsadministratörerna att göra reklam för kommunens åtgärder och visa att den tar problem som rör det mångetniska samhället och minoritetsgrupper på allvar, och ett sätt att få upp frågorna på dagordningen.

\section{Koalitionsbyggande}

Minoritetsadministratörer kommer genom sitt arbete i kontakt med andra aktörer i olika organisationer. Koalitionsbyggande företrädarpraktiker har syftet att länka samman olika aktörer till ett nätverk eller att delta i befintliga koalitioner för att driva frågor som gynnar minoritetsgrupper med större kraft. Minoritetsadministratörer kan till exempel delta i att skapa eller driva lokala, regionala eller nationella nätverk kring sakfrågor. Dessa koalitioner har syftet att skapa en betydelsefull koordinering kring aktiviteter i olika sakfrågor över tid för att få till stånd vissa utfall. Koalitionsbyggande kan till exempel stärka jämlikhetsarbete genom nätverk för mångfalds-, integrations- och stadsutvecklingsfrågor. Genom dessa nätverk förmedlas information om pågående projekt, satsningar, resurser och aktörer. Andra exempel är formella nätverk och organisationer som företräder personal som arbetar med integrationsfrämjande verksamhet, eller nätverk kring mångfaldsfrågor inom Sveriges kommuner och landsting. Genom dessa kanaler ges minoritetsadministratörerna möjligheten 
att påverka lagstiftningsprocesser och annat policyarbete som bedrivs på flera politiska nivåer.

I lokalsamhället kan minoritetsadministratörerna även verka i eller skapa koalitioner som för ihop olika myndigheter och intresseorganisationer. Koalitionerna kan ha syftet att mobilisera resurser för att förbättra situationen i ett bostadsområde, arbeta brottsförebyggande eller motverka rasism och förverkliga integrationspolicy.

\section{Mobilisering}

Mobiliserande företrädarpraktiker inriktar sig på att organisera och stärka minoritetsgrupper som kollektiva aktörer i politiken. Målet är att stärka deras ställning, deltagande och i förlängningen inflytande i politiken för att öka deras möjligheter att forma sina liv efter sina egna behov och intressen. Exempel på mobilisering är att stödja bildandet av föreningar bland enskilda minoritetsgrupper eller att skapa en formell sammanslutning mellan stadens minoritetsföreningar i syfte att öka gruppens inflytande över pågående processer. Det kan innebära att sprida information i samband med val eller att mobilisera minoritetsföreningar till befintliga organ för dialog med kommunens politiker och administratörer. Konkreta aktiviteter är att samla aktörer och föra dialoger om syftet med att förenas och samverka samt att tillhandahålla praktiska möjligheter för möten och dialoger att äga rum. Detta kan inbegripa att vara sammankallande, ordförande och medlare under möten och att som inbjuden gäst föreläsa och fungera som dragplåster för föreningens aktiviteter. Det kan dessutom innebära att samla resurser som stärker mobiliseringen.

\section{Diskussion: representativ byråkrati och demokrati}

Fokus i denna artikel har varit om och i så fall hur offentliga administratörer med minoritetsetnisk bakgrund företräder grupper som de på basis av egna grupptillhörigheter identifierar sig med. Jag har närmare studerat tolv ledande kommunala minoritetsadministratörers verksamhet i olika kontexter.

Slutsatserna är att minoritetsadministratörer kan känna ett ansvar för och en skyldighet att företräda minoritetsgrupper. Företrädarskap defi- 
nierar jag som medvetet handlande för att utifrån den egna identiteten gynna en viss grupp. Minoritetsadministratörernas olika sätt att företräda minoritetsgrupper utifrån sina yrkesroller har systematiserats i sju företrädarpraktiker, eller handlingsmönster, inriktade på dels enskilda ärenden, där enskilda individer och situationer är i fokus, dels övergripande policyfrågor. Minoritetsadministratörer arbetar på olika arenor för att vägleda individer som söker råd och stöd i olika ärenden samt förespråka vissa beslut eller utfall. Minoritetsadministratörerna arbetar också med att skapa, förverkliga och förstärka övergripande politik för ett mångetniskt samhälle internt i organisationen, och i samhället genom att mobilisera och bygga koalitioner med andra aktörer. Det finns en stark koppling mellan företrädarpraktikerna och det företrädarskap som studerats i amerikansk offentlig förvaltning rörande afroamerikanska, latinamerikanska eller icke-västerländska minoritetsgrupper (Karnig och McClain 1988; Thurlow Brenner 2009).

Representation förekommer alltså även inom byråkratin. Inom yrkesrollen driver minoritetsadministratörerna politik med intentionen att vara lyhörda för minoritetsgruppers situation och behov eller uttalade intressen. Min studie visar att sambandet mellan närvaro eller "mångfald" och förändrade beslut i politiska processer kan bero på att de närvarande personerna konkret verkar för att förändra rutiner och processer. Dessutom visar studien att minoritetsadministratörer i Sverige uppfattar företrädarskap och utövar det på ett snarlikt sätt som amerikanska minoritetsadministratörer. Projekten varierar men speglar på ett övergripande plan den ojämlikhet som drabbar minoritetsgrupper i västerländska samhällen.

De svåra frågorna är hur vanligt detta företrädarskap är och vilka förväntningar vi kan ha på det. Min studie ger anledning att tro att offentliga tjänstepersoner som tillhör marginaliserade grupper i samhället och som identifierar sig med dem någon gång under karriären konfronteras med frågor om huruvida de har ett ansvar eller en skyldighet att företräda dem. Det finns ingen policy eller bestämmelse om att minoritetsadministratörer ska företräda minoritetsgrupper, eller att någon annan grupp i förvaltningen ska göra det. I ett samhälle som präglas av ojämlikheter och där etnicitet/ras är en av skiljelinjerna som skapar under- och 
överordning samt avgör tillgången till materiella och symboliska resurser kan vi anta att företrädarskap blir mer eller mindre oundvikligt. Om inte frågan väcks av de enskilda tjänstepersonerna är det troligt att omvärlden aktualiserar den. I de vita homogena organisationer där minoritetsadministratörer rör sig är det stor sannolikhet att omvärlden uppfattar dem som symboler eller representanter för minoritetsgrupper, oavsett vad minoritetsadministratörerna har för åsikt i frågan. Dessutom minskar sannolikheten att undgå frågan om företrädarskap i takt med att samhällsdebatten om rasism, mångfald och demokrati intensifieras. Hur vanligt det är att minoritetsadministratörer ägnar sig åt företrädarskap är dock en angelägen fråga för framtida forskning.

Vilka förväntningar kan vi ha på sambandet mellan närvarons politik i offentlig förvaltning och en politik som är mer lyhörd för minoritetsgruppers behov och intressen? Det finns anledning att tro att företrädarskap påverkar hur politik utformas, hur resurser och auktoritativa värden fördelas utefter vissa gruppers behov och intressen. Huvudtesen i teorin om en representativ byråkrati är att offentliga administratörers företrädarskap har inverkan på utformningen av den offentliga politiken på ett sätt som gynnar den grupp som är i fokus. Även om denna studie visar hur minoritetsadministratörer företräder minoritetsgrupper kvarstår frågan om företrädarpraktikerna påverkar organisationen och politiken i förlängningen. Här kan man skilja mellan å ena sidan de beslut som fattas i organisationen och å andra sidan de resultat de får för samhället.

Vad gäller beslut i organisationen råder det ingen tvekan om att företrädarskap producerar policy samt initierar och förverkligar projekt som manar till förändring av organisatoriska processer och samhällsstrukturer. Men förändras samhällsstrukturer av dessa politiska handlingsprogram? På individnivå har denna studie ingen möjlighet att uttala sig om förändringar. När vi däremot ser på utvecklingen i de fem kommunerna som studerats närmare kan vi konstatera att minoritetsgruppers levnadsvillkor inte förbättrats avsevärt. Den mångetniska ojämlikheten i städerna ökar sett till arbetslöshet, utgifter för försörjningsstöd, boendesegregation, valdeltagande och social oro. Opinionsstödet för rasistiska partier och rasistisk partipolitik har också ökat. Tyder detta på att företrädarpraktikerna inte har några positiva konsekvenser för minori- 
tetsgrupper? Det kan vara möjligt. Men blicken bör också riktas mot den generella politiken och i synnerhet integrations- och mångfaldspolitikens mål, medel och effekter som ofta är en utgångspunkt för företrädarpraktiker på policynivå. Dessutom finns det större globala samhällsförändringar och andra kommunala aktörers intressen och projekt som ökar ojämlikheten.

Minoritetsadministratörernas intention är att inom ramen för rådande policystrukturer och utefter egna politiska projekt få till stånd beslut och verksamhet som bidrar till ett mångetniskt jämlikt samhälle. Dessa projekt förverkligas inom ramen för de offentliga institutionernas institutionella ramverk, dess regler, procedurer, normer och värderingar. Det medför att minoritetsadministratörernas projekt i alla situationer är en kompromiss mellan deras egna ambitioner och rådande ramverk. Mål, begrepp och budgetar kan bändas, tänjas och omtolkas. Men det finns en gräns för vad offentliga administratörer kan åstadkomma: samhälleliga rörelser, politisering i olika sakfrågor, maktresurser i befattningen både tillhandahåller och begränsar det administrativa handlingsutrymmet. Även om företrädarskapet är ett ofullkomligt projekt kan vi konstatera att det förekommer.

Det är dock viktigt att påpeka att minoritetsgrupper inte är en homogen grupp och att de präglas av interna maktrelationer på basis av klass, kön, sexualitet, ålder och därtill en rad religiösa och ideologiska rörelser som har relevans för fastställande av gruppens "egentliga" intressen. En teori om offentliga administratörers företrädarskap och representation i maktpositioner som strategi för minoritetsgrupper måste förhålla sig till detta faktum. Att på essentialistiska grunder utgå från att etniska minoritetsgrupper delar samma ideologiska övertygelser och att de följaktligen skulle kunna enas om på förhand givna värden och intressen är varken teoretiskt eller empiriskt hållbart (jfr Dahlstedt 2005, s. 262). Vilka värden som är angelägna för minoritetsgrupper är en ideologisk och i högsta grad pågående diskussion. Hur den offentliga förvaltningen förhåller sig till denna mångfald av röster och intressen är angeläget att undersöka i framtida forskning.

Slutligen visar denna studie att offentliga administratörer upplever sig vilja företräda minoritetsgrupper och drivs av ideal om ett mång- 
etniskt jämlikt samhälle antingen det ingår i deras formella yrkesroll eller inte. Förvaltning är politik och politiken har en oundviklig administrativ dimension. Detta företrädarskap präglar inte bara minoritetsadministratörer utan bör ses som ett generellt fenomen. Alla tjänstepersoner kan företräda, vilket innebär att homogena organisationer inte företräder hela befolkningen. Offentliga administratörer är inte neutrala robotar utan människor som drivs av vissa passioner och världsbilder, vilket gör att företrädarskap blir en faktor i hur professionella yrkesroller utövas. Syftet med minoritetsadministratörernas företrädarskap är att skapa ett jämlikare samhälle genom att balansera ojämlika levnadsförhållanden. En representativ offentlig förvaltning blir då inte bara en fråga om mångetnisk jämlikhet utan en fråga om generell jämlikhet.

Mångfald, i betydelsen en representativ offentlig förvaltning framträder därför som ett nödvändigt villkor för politisk och social jämlikhet i ett demokratiskt styrelseskick.

\section{Referenser}

Archer, M. 2003. Structure, agency and the internal conversation. Cambridge, Cambridge University Press.

Albrow, M. 1972. Byråkrati. Historia, teori, praktik. Stockholm, Wahlström \& Widstrand. Arendt, H. 2004. The origins of totalitarianism. New York, Shocken Books.

Benavides, A. D. 2006. "Hispanic city managers in Texas. A small group of professional administrators". State and Local Government Review, vol. 38, $\mathrm{nr} 2$. DOI: http://dx.doi.org/IO.II77/0I60323X0603800205

Bengtsson, M. 2012. Anteciperande förvaltning: Tjänstemäns makt $i$ kommunala policyprocesser om vindkraft. Förvaltningshögskolan, Göteborgs universitet.

Bird, K., Saalfeld, T. \& Wüst, A. M. 20IO. The political representation of immigrants and minorities. Voters, parties and parliaments in liberal democracies. Abingdon och New York, Routledge.

Bradbury, M. \& Kellough, J. E. 2008. "Representative bureaucracy. Exploring the potential for active representation in local government". Journal of Public Administration Research and Theory, vol. I8, $\mathrm{nr} 4$. DoI: http://dx.doi.org/IO.IO93/jopart/mumo33

Bradbury, M. \& Kellough, J. E. 20II. "Representative bureaucracy. Assessing the evidence on active representation". The American Review of Public Administration, vol. 4I, nr 2. DoI: http://dx.doi.org/IO.II77/0275074010367823

Bäck, H. \& Soininen, M. 1998. Den kommunala invandrarpolitiken. Arenor, aktörer och barriärer. Stockholm, SNS. 
Chaney, C. K. \& Saltzstein, G. H. 1998. "Democratic control and bureaucratic responsiveness. The police and domestic violence". American Journal of Political Science, vol. 42, nr 3 .

DOI: http://dx.doi.org/I0.2307/2991728

Dahlstedt, M. 2005. Reserverad demokrati. Representation i ett mångetniskt Sverige. Umeå, Boréa.

Dahlstedt, M. \& Hertzberg, F. 2007. "Democracy the Swedish way? The exclusion of 'immigrants' in Swedish politics". Scandinavian Political Studies, vol. 30, $\mathrm{nr} 2$. DoI: http://dx.doi.org/IO.IIII/j.I467-9477.2007.00I77.x

Danermark, B., Ekström, M., Jakobsen, L. \& Karlsson, C. H. 2002. Explaining society. Critical realism in the social sciences. London och New York, Routledge.

Denhardt, J. V. \& Crothers, L. 1998. Street-level leadership. Discretion and legitimacy in front-line public service. Washington, Georgetown University Press.

Dolan, J. 2000. "The senior executive service. Gender, attitudes, and representative bureaucracy". Journal of Public Administration Research and Theory, vol. Io, nr 3.

Ferguson, K. E. 1984. The feminist case against bureaucracy. Philadelphia, Temple University Press.

Fischer, F. 2009. Democracy and expertise. Reorienting policy inquiry. Oxford, Oxford University Press.

Gustafsson, A. 2008. Könsmakt och könsbaserade intressen. Om könspolitisk representation i svensk kommunalpolitik. Göteborg, Förvaltningshögskolan.

Göransson, A. 2005a. Makten och mångfalden. Eliter och etnicitet i Sverige. Rapport frän Integrationspolitiska maktutredningens forskningsprogram. Stockholm, Fritzes offentliga publikationer.

Göransson, A. 2005b. Maktens kön. Kvinnor och män i den svenska makteliten på 200otalet. Stockholm, Natur och kultur.

Henderson, L. J. 1978. "Administrative advocacy and Black urban administrators". The Annals of the American Academy of Political and Social Science, vol. 439, nr I. DOI: http://dx.doi.org/IO.II77/000271627843900I06

Hertzberg, F. 2003. Gräsrotsbyråkrati och normativ svenskhet. Hur arbetsförmedlare förstår en etniskt segregerad arbetsmarknad. Stockholm, Arbetslivsinstitutet.

Hindera, J. J. 1993. "Representative bureaucracy. Further evidence of active representation in the EEOC district offices". Journal of Public Administration Research and Theory, vol. 3 , nr 4 .

Hindera, J. J. \& Young, C. D. 1998. "Representative bureaucracy. The theoretical implications of statistical interaction". Political Research Quarterly, vol. 5I, nr 3. DoI: http://dx.doi.org/I0.1177/106591299805100305

Kalonaityte, V. 2008. Off the edge of the map. A study of organizational diversity as identity work. Lund, Lund Business Press.

Kamali, M. 2002. Kulturkompetens $i$ socialt arbete. Om socialarbetarens och klientens kulturella bakgrund. Stockholm, Carlsson.

Karnig, A. K. \& Mcclain, P. D. 1988. Urban minority administrators. Politics, policy, and style. New York, Greenwood Press. 
Keiser, L. R., Vicki M. Wilkins, Kenneth J. Meijer \& Holland, C. A. 2002. ”Lipstick and logarithms. Gender, institutional context, and representative bureaucracy". American Political Science Review, vol. 96, nr 3. URL: http://www.jstor.org/stable/3117929

Kingsley, J. D. 1944. Representative bureaucracy. An interpretation of the British civil service. Yellow Springs, Antioch Press.

Kranz, H. 1976. The participatory bureaucracy. Women and minorities in a more representative public service. Lexington, Lexington books.

Krislov, S. 1967. The Negro in federal employment. The quest for equal opportunity. Minneapolis, Minnesota University Press.

Levitan, D. M. 1946. "The responsibility of administrative officials in a democratic society". Political Science Quarterly, vol. 6I, nr 4. DOI: http://dx.doi.org/IO.2307/2144373

Martinez, T. R. I99I. "The role of Hispanic public administrators. A theoretical and empirical analysis". The American Review of Public Administration, vol. 2I, nr I. DOI: http://dx.doi.org/I0.II77/027507409102IO0IO3

Meier, K. J. 1984. "Teachers, students, and discrimination. The policy impact of Black representation". The Journal of Politics, vol. 46, $\mathrm{nr}$. DOI: http://dx.doi.org/I0.2307/2130443

Meier, K. J. 1993. "Latinos and representative bureaucracy. Testing the Thompson and Henderson hypotheses". Journal of Public Administration Research and Theory, vol. 3 , nr 4 . URL: http://www.jstor.org/stable/ıi8I685

Meier, K. J. \& Bohte, J. 200I. "Structure and discretion. Missing links in representative bureaucracy". Journal of Public Adminstration Research and Theory, vol. II, nr 4.

Meier, K. J. \& Nicholson-Crotty, J. 2006. "Gender, representative bureaucracy, and law enforcement. The case of sexual assault". Public Administration Review, vol. 66, nr 6. DOI: http://dx.doi.org/I0.IIII/j.I540-6210.2006.00653.x

Meier, K. J. \& Nigro, L. G. 1976. "Representative bureaucracy and policy preferences. A study in the attitudes of federal executives". Public Administration Review, vol. 36, nr 4.

Meier, K. J. \& O’Toole, L. J. 2006. Bureaucracy in a democratic state. A governance perspective. Baltimore, Johns Hopkins University Press.

Meier, K. J., Pennington, M. S. \& Eller, W. S. 2005. "Race, sex, and Clarence Thomas. Representation change in the EEOC”. Public Administration Review, vol. 65, nr 2. DOI: http://dx.doi.org/IO.IIII/j.I540-62I0.2005.00442.x

Mouritzen, P. E. \& Svara, J. H. 2002. Leadership at the apex. Politicians and administrators in Western local governments. Pittsburgh, University of Pittsburgh Press.

Murray, S., Terry, L. D., Washington, C. A. \& Keller, L. F. I994. ”The role demands and dilemmas of minority public administrators. The Herbert thesis revisited". Public Administration Review, vol. 54, nr 5 . DOI: http://dx.doi.org/IO.2307/976425

Norell, P.-O. 1989. De kommunala administratörerna. En studie av politiska aktörer och byråkratiproblematik. Lund, Studentlitteratur. 
Phillips, A. 2000. Närvarons politik. Den politiska representationen av kön, etnicitet och ras. Lund, Studentlitteratur.

Premfors, R. 2003. Demokrati och byråkrati. Lund, Studentlitteratur.

Rocha, R. R. \& Hawes, D. P. 2009. "Racial diversity, representative bureaucracy, and equity in multiracial school districts". Social Science Quarterly, vol. 90, nr 2. DOI: http://dx.doi.org/IO.IIII/j.I540-6237.2009.00620.x

Rodrigo Blomqvist, P. 2005. Närvarons politik och det mångetniska Sverige. Om att ta plats $i$ demokratin. Göteborg, Förvaltningshögskolan.

Rosanvallon, P. 20II. Democratic legitimacy. Impartiality, reflexivity, proximity. Princeton, Princeton University Press.

Saidel, J. R. \& Loscocco, K. 2005. "Agency leaders, gendered institutions, and representative bureaucracy". Public Administration Review, vol. 65, nr 2.

DOI: http://dx.doi.org/I0.IIII/j.I540-62I0.2005.0044I.x

Schierenbeck, I. 2003. Bakom välfärdsstatens dörrar. Umeå, Boréa.

Selden, S. C. 1997. The promise of representative bureaucracy. Diversity and responsiveness in a government agency. New York, M.E. Sharp.

Soininen, M. \& Bäck, H. I999. "Invandrare som medborgare, väljare och politiker", i Amnå, E. (red.), Medborgarnas erfarenheter. Stockholm, Fakta info direkt.

Soydan, H. 1995. Försäkringskassan och invandrarna. Lund, Bokbox.

Svara, J. H. 2006a. "Introduction: Politicians and administrators in the political process - A review of themes and issues in the literature". International Journal of Public Administration, vol. 29, $\mathrm{nr}$ I2. DoI: http://dx.doi.org/I0.I080/oI900690600854555

Svara, J. H. 2006b. "The search for meaning in political-administrative relations in local government". International Journal of Public Administration, vol. 29, nr I2. Dor: http://dx.doi.org/Io.Io8o/or900690600854704

Tahvilzadeh, N. 20II. Representativ byråkrati. En studie om ledande kommunala minoritetsadministratörers företrädarskap. Göteborgs universitet, Förvaltningshögskolan.

Tahvilzadeh, N. \& Karlsson, D. 20Io. "The unrepresentative bureaucracy", i Strömblad, P., Bay, A.-H. \& Bengtsson, B. (red.), Diversity, inclusion and citizenship in Scandinavia. Newcastle, Cambridge Scholars.

Thompson, F. J. 1976. "Minority groups in public bureaucracies. Are passive and active representation linked?" Administration \& Society, vol. 8, nr 2.

DOI: http://dx.doi.org/Io.II77/009539977600800206

Thurlow Brenner, C. 2009. "Latina administrators in local government. The interplay of role orientation and policy intentions". Administration \& Society, vol. 40, nr 8. DoI: http://dx.doi.org/Io.1177/0095399708326346

Wamsley, G. L. m.fl. 1990. Refounding public administration. Newbury Park, Sage.

Wide, J. 2015. Social representativitet $i$ den lokala demokratin. Partierna som politikens grindvakter? Rapport till 2014 års demokratiutredning.

Wilkins, V. M. \& Williams, B. N. 2008. ”Black or blue. Racial profiling and representative bureaucracy". Public Administration Review, vol. 68, $\mathrm{nr} 4$. DoI: http://dx.doi.org/I0.IIII/j.I540-62I0.2008.00905.x 


\title{
Moderna klassiker
}

\section{Norbert Elias}

\author{
John L. Scotson
}

\section{Etablerade och outsiders}

\section{Arkiv förlag}

Norbert Elias (1897-I990) var en av I900-talets mest betydande sociologer. I Etablerade och outsiders (nu tillgänglig i en andra utvidgad upplaga) visar han på ett fascinerande sätt hur moralisk stigmatisering är en allmänt förekommande maktteknik varhelst det finns en konflikt mellan en etablerad och dominerande grupp och en underordnad, dominerad grupp; mellan bofasta och invandrare, vita och svarta i USA, högkastiga och kastlösa indier, män och kvinnor, välbeställda och fattiga.

Arkiv förlag 20IO, 296 sidor 